\title{
LESSON STUDY DALAM PRAKTIK PENGALAMAN \\ LAPANGAN MATAKULIAH MATEMATIKA DASAR 3 \\ S1 PENDIDIKAN MATEMATIKA UNIVERSITAS NEGERI MALANG
}

\author{
Danang Setyadi \\ Program Studi Pendidikan Matematika \\ FKIP-Universitas Kristen Satya Wacana \\ Danang.setyadi@staff.uksw.edu
}

\begin{abstract}
Abstrak
The purposed of this research is to describe the process of on-the-job training using the lesson study which was done by the researcher. The lesson study was applied on the lecture Matematika Dasar 3 in undergraduate program of Pendidikan Matematika FMIPA Universitas Negeri Malang, and there were 40 students selected as subject in total. The lesson study that was applied consisted of three stages that is plan, do, and see. Results obtained in the research showed that students had difficulties in determining the reason of steps or statements they had written, and in distinguishing the use of definition or reverse definition
\end{abstract}

Kata kunci: Lesson study, matematika dasar

\section{PENDAHULUAN}

Guru sebagai tenaga professional berfungsi sebagai agen pembelajaran untuk meningkatkan mutu pendidikan nasional. Sebagai seorang professional, pengembangan profesi guru perlu dilakukan. UU No 14 Tahun 2005 tentang guru dan dosen menyatakan bahwa pengembangan profesi guru meliputi kompetensi pedagogik, kompetensi kepribadian, kompetensi professional, dan kompetensi sosial.

Salah satu alternatif yang dapat digunakan untuk mengembangkan kompetensikompetensi tersebut adalah melalui lesson study. Lesson study merupakan suatu model pembinaan profesi pendidik melalui pengkajian pembelajaran secara kolaboratif dan berkelanjutan berdasarkan prinsip-prinsip kolegalitas dan mutual learning untuk membangun komunitas belajar (Sukirman, 2006; Manrulu dan Novita, 2015).

Rusman (2010) menyatakan bahwa penerapan lesson study dalam pembelajaran memiliki beberapa keunggulan, yaitu meningkatkan pengetahuan guru tentang materi ajar dan pembelajarannya, meningkatkan pengetahuan guru tentang cara mengobservasi aktifitas belajar siswa, menguatkan hubungan kolegalitas baik antar guru maupun dengan observer lain selain guru, menguatnya hubungan antara pelaksanaan pembelajaran seharihari dengan tujuan pembelajaran jangka panjang, meningkatnya motivasi guru untuk senantiasa berkembang, dan meningkatnya kualitas rencana pembelajaran termasuk komponen-komponennya seperti bahan ajar dan strategi pembelajaran.

Secara umum, terdapat tiga tahap dalam pelaksanaan lesson study, yaitu perencanaan (plan), pelaksanaan (do), dan refleksi (see) (Anggara dan Umi, 2012; Suparya, 2016; Mahmudi, 2009; Baba, 2007). Pada tahap perencanaan (plan), guru yang tergabung dalam lesson study secara kolaboratif menyusun RPP yang berpusat pada siswa. Pada tahap pelaksanaan ( $d o)$, perangkat pembelajaran yang telah disiapkan dilaksanakan dalam praktik mengajar. Pada tahap ini, dilakukan pula pengamatan terhadap pelaksanaan pembelajaran tersebut. Pada tahap refleksi (see), seluruh pihak yang terlibat dalam aktivitas pengamatan melakukan refleksi untuk mendiskusikan pembelajaran yang telah dilakukan. Dalam tahap ini, pembahasan tidak dimaksudkan 
untuk mengomentari aktivitas guru ketika melaksanakan pembelajaran, melainkan lebih diarahkan pada hasil pengamatan terhadap perilaku siswa selama proses pembelajaran di kelas.

Mahasiswa S2 Pendidikan Matematika Universitas Negeri Malang yang disiapkan sebagai calon pendidik professional telah melakukan praktik KPL dengan menggunakan lesson study. Penerapan lesson study tersebut diharapkan dapat digunakan sebagai bekal yang bermanfaat dalam pengembangan diri di masa depan.

\section{KAJIAN PUSTAKA \\ Hakekat Lesson Study}

Lesson study merupakan terjemahan dari frasa jepang jugiokenkyo yang merujuk pada suatu proses sistematik yang digunakan oleh guru-guru Jepang untuk meningkatkan keefektifan pengajarannya yang telah dilakukan selama lebih dari 100 tahun (Makinae, 2010). Lesson study pertama kali dikenalkan kepada komunitas pendidikan internasional melalui publikasi Teaching Gap (Stigler dan Hiebert, 1999).

Lesson study bukanlah suatu strategi atau metode dalam pembelajaran, tetapi merupakan salah satu upaya pembinaan untuk meningkatkan proses pembelajaran yang dilakukan oleh sekelompok guru secara kolaboratif dan berkesinambungan, dalam merencanakan, melaksanakan, mengobservasi dan melaporkan hasil pembelajaran (Melati, Junanto, dan Lestari, 2014). Lesson study merupakan proses terstruktur dimana guru bekerja secara bersama-sama untuk merumuskan solusi-solusi dari tantangantantangan yang mereka hadapi ketika melakukan proses pembelajaran (MDT, 2017; Baba, 2007).

Secara lebih rinci, Mahmudi (2009) menyatakan lesson study merupakan suatu proses kolaboratif dari sekelompok guru untuk secara bersama-sama (1) mengidentifikasi masalah pembelajaran yang dirasakan oleh guru, (2) merencanakan langkah-langkah pembelajaran untuk memecahkan masalah tersebut, (3) melaksanakan pembelajaran yang dilakukan oleh salah satu guru yang dipilih/disepakati, sementara guru yang lain melakukan observasi, (4) mengevaluasi proses pembelajaran yang telah dilakukan, (5) memperbaiki perencanaan pembelajaran berdasarkan hasil evaluasi, (6) melaksanakan pembelajaran lagi, (7) mengevaluasi kembali pembelajaran yang telah dilaksanakan, dan (8) menyebarluaskan pengalaman dan temuan dari hasil evaluasi tersebut kepada guru yang lain. Langkah-langkah tersebut dapat dikelompokkan ke dalam tiga tahap yaitu plan, do, dan see.

\section{Ciri-ciri Lesson Study}

Lewis (2004) mengemukakan bahwa terdapat empat ciri lesson study, yaitu adanya tujuan untuk jangka panjang, penekanan pada materi pembelajaran yang penting, penekanan pada studi tentang siswa secara cermat, dan mengutamakan observasi pembelajaran secara langsung.

Lesson study diawali dengan kesepakatan mengenai tujuan bersama yang perlu ditingkatkan dalam jangka waktu tertentu, misalnya pengembangan kemampuan akademik siswa. Tujuan bersama tersebut perlu ditekankan pada materi yang dianggap penting dan menjadi titik lemah bagi siswa. Pada saat pelaksanaan, pusat perhatian bukan lagi bagaimana guru mengajar namun lebih fokus pada aktivitas belajar siswa. 


\section{Manfaat Lesson Study}

Sebagai salah satu model pengembangan profesi guru lesson study memiliki beberapa manfaat, yaitu: mengurangi keterasingan guru, menciptakan suasana keakraban dan kekeluargaan antar sesama guru, memberi peluang bagi guru untuk memecahkan masalah dan menciptakan solusinya secara bersama-sama serta saling bertukar pengalaman, guru dapat membuat perencanaan pembelajaran secara bersama-sama dan mempraktekan hasil kerjanya, dan membuat guru menjadi lebih profesional dalam mengajar sehingga menciptakan suasana belajar yang kondusif bagi siswa (Sukirman, 2006; Anggara dan Chotimah, 2012).

\section{METODE PENELITIAN}

Penelitian ini termasuk penelitian deskriptif yang bertujuan mendeskripsikan proses pelaksanaan praktik pengalaman lapangan dengan menggunakan lesson study yang telah dilakukan peneliti. Lesson study diterapkan pada matakuliah Matematika Dasar 3 di S1 Pendidikan matematika FMIPA Universitas Negeri Malang dengan subjek berjumlah 40 mahasiswa. Lesson study yang diterapkan terdiri dari dua siklus yang masing-masing siklus terdiri dari dua pertemuan. Masing-masing pertemuan tersebut terdiri dari tiga tahapan, yaitu perencanaan (plan), pelaksanaan (do), dan refleksi (see). Instrumen yang digunkan terdiri dari RPP, Lembar Soal, dan Lembar Observasi. Data penelitian diperoleh dari jawaban siswa, analisis hasil observasi dan transkrip wawancara. Triangulasi yang digunakan adalah triangulasi metode. Hasil analisis dari lembar soal, lembar observasi, dan transkrip wawancara tersebut dibandingkan untuk mengetahui data yang sebenarnya. Agar data yang diperoleh benar-benar apa adanya, peneliti juga membandingkan hasil analisis tersebut dengan video proses pelaksanaan pembelajaran.

\section{HASIL DAN PEMBAHASAN}

Proses perkuliahan yang dilaksanakan peneliti pada materi aplikasi dari postulatpostulat geometri menggunakan lesson study. Uraian dari pelaksanaan lesson study tersebut adalah sebagai berikut.

\section{Analisis Perencanaan Perkuliahan (Plan)}

Materi yang digunakan dalam pelaksanaan perkuliahan merupakan aplikasi dari postulat-postulat geometri. Materi aplikasi dari postulat-postulat geometri tersebut selanjutnya didiskusikan dengan anggota kelompok. Hal ini dilakukan agar peneliti menguasai materi yang akan digunakan tersebut.

Pada tahap berikutnya, peneliti bersama anggota kelompok menyusun perangkat perkuliahan berupa RPP, uraian materi, soal tugas, pedoman penskoran, dan lembar observasi. RPP disusun sebelum pelaksanaan perkuliahan. Penyusunan RPP menggunakan RPP lima kolom. Kolom RPP terdiri dari tindakan dosen, tujuan tindakan, kemungkinan reaksi mahasiswa, rencana respon dosen terhadap reaksi mahasiswa, dan evaluasi. Model pembelajaran yang digunakan adalah kooperatif dan metode pembelajaran yang digunakan adalah ceramah, diskusi, dan tanya jawab.

Penyusunan perangkat perkuliahan tersebut dilakukan secara berkelompok. Peneliti berdiskusi dengan anggota kelompok untuk menyusun uraian materi, langkahlangkah pembelajaran, dan soal yang dipilih untuk digunakan sebagai tugas. Pada tahap ini, peneliti juga berdiskusi tentang pembagian masalah yang akan diberikan kepada mahasiswa dan urutan presentasi yang akan dilakukan oleh mahasiswa. Pada penyususunan RPP, peneliti mendapatkan saran dari dosen pembibing KPL yaitu setiap 
kelompok mahasiswa hendaknya melakukan presentasi satu masalah terlebih dahulu, sehingga masing-masing kelompok memiliki kesempatan untuk mempresentasikan pekerjaannya.

\section{Analisis Pelaksanaan Perkuliahan (Do)}

Pada bulan september 2016 dilaksanakan praktik perkuliahan pada materi aplikasi dari postulat-postulat geometri. Perangkat perkuliahan yang digunakan adalah RPP, uraian materi, soal tugas, pedoman penskoran, dan lembar observasi.

Pelaksanaan perkuliahan sesuai dengan perencanaan perkuliahan yang telah disusun. Pada kegiatan awal, peneliti telah menyampaikan apersepsi dengan mengingatkan kembali tentang definisi dan postulat yang telah mahasiswa pelajari dan telah menjelaskan tentang agenda yang akan dilakukan pada pelaksanaan perkuliahan. Pada kegiatan inti, mahasiswa melakukan presentasi sesuai dengan urutan yang telah direncanakan yaitu kelompok 1, kelompok 7, kelompok 2, kelompok 6, kelompok 3, kelompok 5, dan kelmpok 4. Secara umum mahasiswa melakukan presentasi dengan baik dimana terjadi diskusi antar mahasiswa yang satu dengan mahasiswa yang lain. Ketika mahasiswa telah melakukan presentasi, peneliti telah memberikan pertanyaan dan memberikan penekanan pada bagian tertentu. Peneliti juga menjelaskan materi yang tidak dapat diselesaikan oleh mahasiswa. Pada tahap berikutnya, peneliti memberikan tiga soal kepada masing-masing mahasiswa sebagai tugas. Tugas ini bertujuan agar mahasiswa lebih terampil dalam menyelesaikan masalah yang diberikan. Pada kegiatan penutup, peneliti meminta mahasiswa untuk mempelajari lagi materi yang telah dipelajari tersebut.

Pada pelaksanaan perkuliahan terdapat interaksi antara mahasiswa dengan mahasiswa dan mahasiswa dengan peneliti. Interaksi antara mahasiswa dengan mahasiswa terjadi ketika mereka saling berdiskusi tentang masalah yang sedang dipresentasikan dan ketika mereka berdiskusi tentang tugas yang dikerjakan. Interaksi antara mahasiswa dengan peneliti terjadi ketika mahasiswa menjawab pertanyaan peneliti pada kegiatan apersepsi dan ketika mahasiswa mengalami kesulitan tentang masalah yang dipresentasikan.

\section{Analsis Refleksi Perkuliahan (See)}

Refleksi perkuliahan dilaksanakan oleh peneliti sesaat setelah selesai melakukan perkuliahan. Berdasarkan pengamatan observer diperoleh hasil pengamatan sebagai berikut.

1. Terdapat interaksi antara mahasiswa dengan mahasiswa yaitu ketika mereka saling berdiskusi tentang masalah yang sedang dipresentasikan dan ketika mereka berdiskusi tentang tugas yang dikerjakan.

2. Terdapat interaksi antara mahasiswa dengan peneliti yaitu ketika mahasiswa menjawab pertanyaan peneliti pada kegiatan apersepsi dan ketika mahasiswa mengalami kesulitan tentang masalah yang dipresentasikan.

3. Ada mahasiswa yang kurang memperhatikan ketika mahasiswa dari kelompok lain melakukan presentasi. Hal ini karena mahasiswa tersebut sibuk bermain smartphone dan membicarakan sesuatu dengan temannya.

4. Beberapa mahasiswa mengalami kesulitan dalam membedakan penggunaan definition atau reverse of definition.

5. Beberapa mahasiswa mengalami kesulitan dalam menentukan alasan (reason) dari langkah atau pernyataan yang telah ia tuliskan. 
6. Sebagian besar mahasiswa mengalami kesulitan ketika mengerjakan atau menyelesaikan masalah halaman 82 nomor 5.

Berdasarkan hasil pengamatan tersebut, diketahui bahwa beberapa mahasiswa mengalami kesulitan dalam menentukan alasan (reason) dari langkah atau pernyataan yang telah ia tuliskan dan mengalami kesulitan dalam membedakan penggunaan definisi atau reverse definisi. Perbaikan yang dapat dilakukan adalah mahasiswa seharusnya berlatih membedakan definisi dan reverse definisi. Mahasiswa seharusnya tidak hanya memiliki ringkasan tentang definisi-definisi dan postulat, namun juga menuliskan reverse definisi pada ringkasannya tersebut. Selanjutnya, diketahui pula bahwa sebagian besar mahasiswa mengalami kesulitan ketika mengerjakan atau menyelesaikan masalah halaman 82 nomor 5. Hasil wawancara menunjukkan bahwa mahasiswa selalau mengartikan istilah intersect dengan berpotongan, padahal istilah tersebut tidak hanya berarti berpotongan. Pada saat menjawab pertanyaan, mahasiswa seharusnya selalu menuliskan alasan (reason) dari setiap langkah yang ditulis.

\section{SIMPULAN}

Hasil penelitian menunjukkan bahwa ketiga tahapan lesson study telah dilaksanakan dengan benar. Pada tahap plan, peneliti bersama anggota kelompok menyusun perangkat perkuliaha berupa RPP, uraian materi, soal tugas, pedoman penskoran, dan lembar observasi. RPP disusun sebelum pelaksanaan perkuliahan. Penyusunan RPP menggunakan RPP lima kolom. Pada tahap pelaksanaan (do), peneliti melaksanakan perencanaan yang telah disusun. Pelaksanaan pembelajaran terdiri dari kegiatan awal, kegiatan inti, dan kegiatan penutup. Pada tahap refleksi (see), peneliti bersama observer melaksanakan perefleksian pada kegiatan pembelajaran yang telah dilakukan.

Temuan penelitian bahwa beberapa mahasiswa mengalami kesulitan dalam menentukan alasan (reason) dari langkah atau pernyataan yang telah ia tuliskan dan mengalami kesulitan dalam membedakan penggunaan definition atau reverse definition menunjukkan bahwa guru perlu memberikan penjelasan lebih mendalam mengenai hal tersebut.

\section{DAFTAR PUSTAKA}

Anggara, R., dan Umi, C. 2012. Penerapan lesson study berbasis musyawarah guru mata pelajaran (MGMP) terhadap peningkatan kompetensi profesional guru PKn SMP se-kabupaten Ogan Ilir. Jurnal Forum Sosial. V(02).

Baba, T. 2007. How is lesson Study Implemented? Dalam Isoda, M, Ohara, Y, dan Miyakawa, T. (Ed). Japanese Lesson Study in Mathematics Its Impact, Diversity and Potential for Educational Improvement New Jersey USA: Worl Scientific Publishing Co. Pte. Ltd.

Lewis, C. 2004. Does Lesson Study Have a Future in the United States? (Online]). (http://www.sowi-online.de/journal/2004-1/lesson_lewis.htm, diakses 19 November 2018).

Mahmudi, A. Mengembangkan Kompetensi Guru Melalui Lesson Study. Forum Kependidikan, 29(2)

Makinae, N. 2010. The Origin of Lesson Study in Japan. (Online). (http://www.lessonstudy.net/lg/readingsTheOriginofLessonStudyinJapanMakina eN/pdf, diakses 22 Maret 2019). 
Manrulu, R.H., dan Novita, D. S. 2015. Efektivis kegiatan lesson study dalam merancang pembelajaran pada matakuliah gelombang dan optik. Jurnal ilmiah pendidikan fisika 'Al-BiruNi', 4(2)

Maths Development Team. 2017. A Handbook for Lesson Study: Including a Research Lesson Proposal Template.

(Online).(https://www.projectmaths.ie/documents/LessonStudy1718/LessonStud yHandbook.pdf,_diakses 11 Januari 2018).

Melati, H. A., Junanto, T., dan Lestari, I. 2014. Lesson Study Untuk Meningkatkan Kualitas Pembelajaran English For Chemistry 1. Makalah. Dipublikasikan pada Seminar Nasional 2014.

Rusman. 2010. Model-Model Pemebelajaran Mengembangkan Profesionalisme Guru. Bandung: Raja Grafindo Persada

Stigler,J., dan Hiebert, J. 1999. The teaching gap: Best ideas from the world's teachers for improving education in the classroom. New York: Free Press

Sukirman. 2006. Peningkatan Profesional Guru Melalui Lesson Study. Makalah Disampaikan Pada Kegiatan Pelatihan 2 Hari untuk Fasilitator dan Tim TPK SISTIEMS Bantul Emergency Program, 11-12 Agustus 2006.

Suparya, I. K. 2016. Penerapan Model Problem Base Learning Melalui Lesson Study Untuk Meningkatkan Kemampuan Berpikir Kritis Pada Mahasiswa Jurusan Pendidikan Guru Pendidikan Anak Usia Dini. Jepun, 1(1)

Undang-Undang Nomor 14 tahun 2005 tentang Guru dan Dosen. Jakarta: Asa mandiri. 